\title{
ÁL-FÂHIM
}

\section{Jurnal Manajemen Pendidikan Islam}

Manajemen Strategi Pemasaran Pendidikan

Di SDIT Alam Nurul Islam Sleman

Jamaludin

Menakar Kebijakan Pendidikan Nasional Dan Pendidikan Islam Di Indonesia Era Reformasi (Presiden Habibie Sampai Presiden Jokowi Jilid I) Permana Octofrezi

Peran Kepala Sekolah Dalam Implementasi Manajemen Mutu

Peserta Didik (Smk Darul Maghfiroh Di Sinar Rejeki, Kecamatan Jati Agung, Kabupaten Lampung Selatan) Andrianto

Konsep Ulul Albab Dalam Manajemen Kepemimpinan Pendidikan Islam Nimas Wegig Kurniana

Analisis Kritis Kepemimpinan Pendidikan Islam Berdasarkan Syarat Dan Ciri-Ciri Kepemimpinan Yang Ideal Siti Qurrotul A'yuni, Radia Hijrawan

Menjadi Pemimpin Yang Efektif Dan Berpengaruh

Di Madrasah Munganatul Khoeriyah

Upaya Sekolah Dalam Meningkatkan Prestasi Non Akademik Siswa Melalui Manajemen Sarana Prasarana Di SMP Muhammadiyah Boarding School Pleret Safinatun Munawaroh, Rz. Ricky Satria Wiranata

Diterbitkan Oleh:

Prodi Manajemen Pendidikan Islam STAIT Yogyakarta 


\section{$\frac{\text { ÁL-FÂHIM }}{\text { Jurnal Manajemen Pendidikan stam }}$}




\section{ÁL-FÂHIM \\ Jurnal Manajemen Pendidikan Islam}

$\begin{array}{ll}\text { Penangung Jawab } & \text { : Danang Dwi Prasetyo } \\ \text { Ketua Redaksi } & \text { : Rz. Ricky Satria Wiranata } \\ \text { Editor } & \text { : Denas Hasman Nugraha } \\ \text { Reviewer } & \text { : Syarif Hidayat } \\ & \text { Suprih Hidayat } \\ \text { Tata Usaha } & \text { Sulis Ariawan } \\ & \text { Nita Kumalasari } \\ \text { Penerbit } & \text { Sekolah Tinggi Agama Islam Terpadu } \\ & \text { Yogyakarta } \\ \text { Alamat Redaksi } & \text { : Jl. Mendung warih No. 125 Giwangan, } \\ & \text { Umbulharjo, Yogyakarta } \\ & \text { Telp. (0274) 410350, 4281163 } \\ & : \text { redaksialfahim@gmail.com } \\ \text { Email } & \text { : jurnal.staitbiasjogja.ac.id } \\ \text { Website } & \end{array}$

\section{Deskripsi:}

ÁL-FÂHIM adalah jurnal Manajemen Pendidikan Islam yang diterbitkan secara berkala selama enam bulan sekali oleh Prodi Manajemen Pendidikan Islam Sekolah Tinggi Agama Islam Terpadu Yogyakarta berdasarkan Keputusan Ketua STAIT Jogja Nomor 001/A.KEP/STAITJOGJA/II/2019 tanggal 18 Februari 2019. Jurnal ÁL-FÂHIM adalah sarana kaum intelektual sebagai media informasi dan penyebarluasan hasil studi penelitian dan artikel ilmiah dibidang Manajemen Pendidikan Islam.

Jurnal ÁL-FÂHIM mengundang para Dosen, Pendidik dan praktisi Pendidikan Islam untuk menyumbangkan karya ilmiahnya di bidang Manajemen Pendidikan Islam. Naskah yang dikirim akan diseleksi dan dipublikasikan sesuai aturan dan ketentuan yang berlaku. Karya Ilmiah yang dimuat di Jurnal ÁLFÂHIM tidak selamanya mencerminkan pendapat redaksi. 
DAFTAR ISI

Vol. 02 No. 02 September 2020

Halaman Judul .................................................................................. $\mathrm{i}$

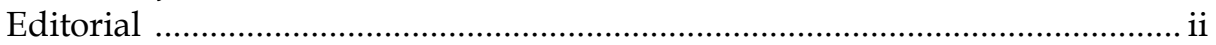

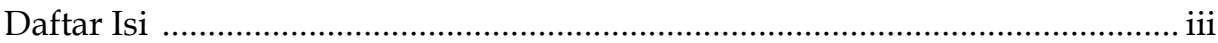

Manajemen Strategi Pemasaran Pendidikan Di SDIT Alam Nurul Islam Sleman

Jamaludin

Menakar Kebijakan Pendidikan Nasional Dan Pendidikan Islam Di

Indonesia Era Reformasi (Presiden Habibie Sampai Presiden Jokowi Jilid I)

Permana Octofrezi

Peran Kepala Sekolah Dalam Implementasi Manajemen Mutu Peserta Didik (SMK Darul Maghfiroh Di Sinar Rejeki, Kecamatan Jati Agung, Kabupaten Lampung Selatan)

Andrianto

Konsep Ulul Albab Dalam Manajemen Kepemimpinan Pendidikan Islam

Nimas Wegig Kurniana

Analisis Kritis Kepemimpinan Pendidikan Islam Berdasarkan Syarat Dan Ciri-Ciri Kepemimpinan Yang Ideal

Siti Qurrotul A'yuni, Radia Hijrawan ........................................................................ 68

Menjadi Pemimpin Yang Efektif dan Berpengaruh di Madrasah

Munganatul Khoeriyah

Upaya Sekolah Dalam Meningkatkan Prestasi Non Akademik Siswa Melalui Manajemen Sarana Prasarana Di SMP Muhammadiyah Boarding School Pleret

Safinatun Munawaroh, Rz. Ricky Satria Wiranata 


\title{
Analisis Kritis Kepemimpinan Pendidikan Islam Berdasarkan Syarat Dan Ciri-Ciri Kepemimpinan Yang Ideal \\ Siti Qurrotul A'yuni, Radia Hijrawan \\ Universitas Islam Negeri Sunan Kalijaga Yogyakarta \\ sitiqurrotulayuni95@gmail.com, radiahijrawan21@gmail.com
}

\begin{abstract}
Islamic education institutions are places that accommodate all Islamic educational activities. In it consists of individuals to form a group. Talking about groups, of course there is someone who stands out the most and can influence others, based on that fact the term leader appears, where the process of influencing and organizing activities in the group is called leadership. The process of leadership in an educational institution has an important role for the sustainability and success of an institution. The library research method is the method used by the author in analyzing Islamic education leadership. Compiled from several literature studies in the form of print and digital, then an analysis is carried out related to ideal leadership based on its terms and characteristics, the results obtained are inevitable where there is no single leader with perfection. There is no patent formula or theory that is used by the leadership to lead the institution. However, ideal in the sense here, can be interpreted as leadership in accordance with the circumstances and conditions of the institution he leads.
\end{abstract}

Keyword: Leadership, Islamic Education

\section{Pendahuluan}

Pendidikan merupakan usaha sadar yang dengan sengaja dirancang untuk mencapai tujuan yang telah ditetapkan. Pendidikan bertujuan untuk meningkatkan kualitas sumber daya manusia ialah melalui proses pembelajaran di sekolah.101 Lembaga pendidikan merupakan wadah yang menampung seluruh aktivitas pendidikan. Madrasah Dinyah, Sekolah Islam, Pondok Pesantren, Ma'had 'Ali adalah contoh lembaga pendidikan Islam di Indonesia. Dalam mengelola dan mengatur seluruh aktivitas pendidikan tersebut, membutuhkan seorang yang disebut pemimpin. Kepala madrasah, kepala sekolah, dan Kiyai adalah contoh pemimpin dalam lembaga pendidikan tersebut.

Tugas dasar pemimpin adalah membentuk dan memelihara lingkungan dimana manusia bekerjasama dalam suatu kelompok yang terorganisir dengan baik, menyelesaikan tugas mencapai tujuan yang telah ditetapkan. Kemudian, pemimpin yang efektif adalah pemimpin yang anggotanya dapat merasakan bahwa kebutuhan mereka terpenuhi, baik kebutuhan bekerja, motivasi, rekreasi, kesehatan, sandang, pangan, tempat

101 Jasmani Asf, Syaiful Mustofa, Supervisi Pendidikan: Terobosan Baru dalam Peningkatan Kinerja Pengawas Sekolah dan Guru (Jogjakarta: AR-RUZZ MEDIA, 2013), hal. 15. 
tinggal, maupun kebutuhan lainnya. Pendek kata, semua kebutuhan anggota dalam organisasi terpenuhi dengan baik. ${ }^{102}$ Jadi pada hakikatnya seorang pemimpin memiliki tanggung jawab besar terhadap anggota dan lembaganya.

Bahasan tentang pemimpin tentu tak lepas dari kepemimpinan (proses pemimpin mempengaruhi anggotanya). Kepemimpinan merupakan keniscayaan yang tidak bisa dipisahkan dari realitas, karena memimpin dan dipimpin merupakan bagian dari kehidupan. Seorang kepala negara adalah pemimpin bagi rakyatnya, seorang ketua suatu organisasi adalah pemimpin bagi anggotanya, seorang guru adalah pemimpin bagi murid-muridnya, kepala sekolah adalah pemimpin di lembaga pendidikannya, seoarang ayah adalah pemimpin dalam keluarganya, bahkan setiap manusia adalah pemimpin bagi dirinya sendiri. Karena pada hakikatnya, kehadiran manusia di muka bumi sudah mengemban amanah kekhalifahan atau kepemimpnan untuk melayani, pengabdi dan bahkan untuk menjaga dan mengatur bumi dengan sebaik-baiknya guna tercipta kehidupan yang damai dan tentram. ${ }^{103}$ Pembahasan pada tulisan ini penulis anggap penting, karena sebagai calon pengelola pendidikan Islam hendaknya akademisi Pendidikan Islam mampu menganalisis tentang syarat dan ciri-ciri pemimpin pendidikan Islam. Sehingga kelak lembaga pendidikan Islam dapat mencetak insan kamil sebab terlaksananya kepemimpinan oleh pimpinan profesional.

\section{Metode Penelitian}

Metode penelitian adalah prosedur atau langkah-langkah dalam mendapatkan pengetahuan ilmiyah. Metode penelitian juga merupakan cara sistematis untuk menyusun suatu karya ilmiyah agar mencapai tujuan tertentu. ${ }^{104}$ Adapun dalam penyusunan mini riset ini menggunakan Penelitian Kepustakaan (Library Research), dimana penulis mencari data dari berbagai literasi di perpustakaan yang berhubungan dengan judul penelitian, baik melalui media cetak maupun digital. Disebut penelitian kepustakaan karena data-data atau bahan-bahan yang diperlukan dalam menyelesaikan penelitian tersebut menggunakan objek penelitian dari perpustakaanbaik berupa buku-buku, ensklopedi, kamus, jurnal, dokumen, majalah dan lain sebagainya. ${ }^{105}$

102 Syaiful Sagala, Administrasi Pendidikan Kontemporer, (Bandung: Alfabeta, 2013), hal. 143.

103 Muhammad 'Abduh dan Muhammad Rasyid Ridha, Tafsir al-Mannar (al-

Qahirah: Dar al-Mannar, 1947), hal. 258.

104 Sutrisno Hadi, Metodologi Riset, (Yogyakarta: Pustaka Pelajar, 2015). Hal , 4

105 Nursapia Harahap, Penelitian Kepustakaan, Jurnal Iqra' Volume 08 No.01

Mei, 2014. hal. 16. 


\section{Pembahasan}

\section{Arti Pemimpin dan Kepemimpinan Pendidikan Islam}

Membahas tentang pemimpin, akan lebih baik jika terlebih dahulu mengetahui asal-usul seorang pemimpin menurut para ahli. Menurut beberapa teori tentang munculya pemimpin antara lain: 106

1. Teori Heriditas (keturunan)

Teori ini di pelopori oleh Galton, menurutnya pemimpin itu muncul dari keturunan orang-orang terkemuka. Jika ayah menjadi pemimin, maka kelak anaknya akan menggantikan, kemudian ketika lengser akan digantikan kembali oleh cucunya, dan begitu seterunya.

2. Teori Environmental

Munculnya pemimpin adalah sebab kemampuan dan keterampilan yang memungkinkan dia memecahkan masalah sosial di lingkungannya.

3. Teori Humanstik

Dalam teori ini yang memerhatikan kebutuhan-kebutuhan yang ada dalam kelompok organisasinya, dalam artian ,jika terdapat suatu organisasi, maka harus ada pemimppin di dalamnya.

4. Teori fitrah

Berangkat dari suatu asumsi bahwa manusia merupakan makhluk sosial, yang diciptakan menjadi seorang pemimpin. Dahulu teori ini diciptakan untuk menggantikan kenabian dalam rangka menjaga agama dan mengatur dunia.

Manusia diciptakan di dunia pada hakikatnya adalah sebagai pemimpin dimuka bumi. Tidak perlu memandang jauh sebagai pimpinan suatu negara, dalam ruang lingkup kecil manusia merupakan pemimpin bagi dirinya sendiri. Hal tersebut termaktub dalam kalamullah yang berbunyi:

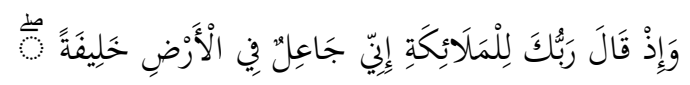

Ingatlah ketika Tuhanmu berfirman kepada para Malaikat:

"Sesungguhnya Aku hendak menjadikan seorang khalifah di muka bumi". (Q. S. Al-Baqarah: 30)107

Pemimpin adalah seseorang yang mampu mempengaruhi orang lain untuk melakukan atau tidak melakukan sesuatu. ${ }^{108}$ Pemimpin adalah orang yang memimpin. Menurut kamus besar bahasa Indonesia artinya membimbing, menuntun, mengarahkan, mengepalai. Jadi pemimpin adalah

106 Muhadi Zainuddin dan Abd. Mutaqim, Studi Kepemimpinan Islam: Konsep, Teori, dan Praktiknya dalam Sejarahal. (Yogyakarta: SUKA Press, 2012), hal. 3-8.

107 Surat Al-Baqarah (3:30) https://quran.kemenag.go.id/index.php/sura/3 diakses pada tanggal 11 September 2020.

108 Matondang, Kepemimpinan: Budaya Organisasi dan Manajemen Strategik, (Yogyakarta: Graha Ilmu, 2008), hal. 5. 
orang yang mampu membimbing, menuntun, mengarahkan, ataupun mengepalai. 109

Sedangkan kepemimpinan merupakan kata imbuhan yang berasal dari kata pemimpin, yang memuat dua hal pokok yaitu: pemimpin merupakan subjek, dan yang dipimpin adalah objek. Secara sederhana adalah kemampuan yang dimiliki seseorang untuk mempengaruhi orang lain. Pemimpin mempunyai tanggung jawab baik secara fisik maupun spiritual terhadap keberhasilan aktivitas kerja dari yang dipimpin. ${ }^{110}$ Jika diamati lebih mendalam tentang pemimpin dan kepemimpinan ini, tidaklah mudah. Karena setiap orang memiliki ciri dan karakteristik tersendiri dalam mempengaruhi seseorang. Sehingga menghasilkan sesuatu yang berbeda pula.

Kepemimpinan dalam bahasa inggris disebut dengan leadership. George R. Terry menyatakan "Leadership is the relationship in whichone person, or the leader, influences other to work together willingly or related taks to attain that which the leader desires". 111 Kepemimpinan adalah hubungan yang ada dalam diri seseorang atau pemimpin. Mempengaruhi orang lain untuk bekerjasama secara sadar untuk mencapai tujuan.

George R. Terry di dalam buku Kartini Kartono juga mengungkapkan beberapa teori kepemimpinan,112 yaitu:

a. Teori Otakratis dan Pemimpin Oraktis. Kepemimpinan dalam teori ini di dasarkan oleh perintah-perintah, paksaan dan tindakan yang abriter. Kepemimpinan yang berorientasi pada struktur organisasi dan tugastugas.

b. Teori Psikologis. Kepemimpinan dalam teori ini dimana sosok pemimpin memunclkan dan mengembangkan sistem motivasi terbaik untuk merangsang kesediaan bekerja para pengikut dan anak buah.

c. Teori Sosiologis. Pada teori ini kepemimpinan dianggap sebagai usahausaha untuk melancarkan antara relasi dalam organisasi dan sebagai usaha untuk menyelesaikan setiap konflik oraganisatoris antara para pengikutnya.

d. Teori Suportif. Teori ini mengatakan para pengiutnya harus berusaha sekuat mungkin dan bekerja penuh gairah, sedang pemimpin akan membimbing dengan sebaik-baiknya melalui policy tertentu.

109 Nawas Syarif, "Menyambut Kepemimpinan Ideal di tengah Maraknya Kepemimpinan Transaksional" http://pemberiilmu.blogspot.com/2013/02/ menyambut-kepemimpinan-ideal-di-tengahal.html (diakses pada tanggal 5 Oktober 2019).

110 Jerry HAL. Makawimbang, Kepemimpinan Pendidikan yang Bermutu, (Bandung: Alfabeta, 2012), hal. 6.

111 Ibid., hal. 8.

112 Imam Machali dan Ara Hidayat, The Handbook Of Education Management, (Jakarta: Kencana, 2018), hal. 87-89. 
e. Teori Laissez Faire. Teori ini menyatakan bahwa seorang pemimpin yang tidak mampu mengurus dan dia menyerahkan tanggung jawabannya serta pekerjaan kepada bawahannya.

f. Teori Kelakuan Pribadi. Teori kemepmimpinan seperti ini akan muncul berdasarkan kualitas pribadi atau pola kelakuan para pemimpin. Pemimpin harus mampu mengambil langkah-langkah tertentu untuk mengatasi masalah.

g. Teori Sifat Orang-orang Besar. Cikal bakal seorang pemimpin dapat dilihat dan diprediksi dengan melihat sifat, karakter, dan perilaku orangorang besar yang terbukti sudah sukses dalam menjalankan kepemimpinannya

h. Teori Situasi. Teori situasi berpandangan bahwa muncunya seorang pemimpin bersamaan dengan masa pergolakan kritis, seperti revolisi dan pemberontakan. Pada saat itu akan muncul seorang pemimpin yang mampu mengatasi persoalan-persoalan yang nyaris tidak dapat diselesaikan oleh orang " biasa".

i. Teori Humanistik/Populistik. Kepemimpinan menurut teori ini merealisasikan kebebasan manusia dan memenuhi kebutuhan setiap insani, yang dicapat melalui interaksi pemimpin dengan rakyat.

\section{Teori Kepemimpinan Pendidikan Islam}

Islam tidak jauh berbeda dalam memandang kepemimpnan dengan model kepemimpinan pada umumnya, sebab prinsip dan sistem yang digunakan terdapat kesamaan. Kepemimpinan dalam Islam dapat mencontoh kepemimpinan Rasullah SAW sebagai pemimpin spiritual dan masyarakat pada masa itu. Beliau mengutamakan uswatun hasanah atau memberi contoh yang baik kepada para sahabatnya yang dipimpin. Hal ini termaktub dalam al-Qur'an surat al-Qalam ayat 4;

$$
\text { وَإِنَّكَ لَعَلَى خُلُقِ عَظِيْمِ }
$$

"Dan sesungguhnya engkau Muhammad benar-benar berada dalam akhlak yang agung." 113

Berdasarkan ayat diatas menunjukkan bahwa Rasullah memiliki kelebihan berupa akhlak mulia, sehingga dalam perihal memimpin tidak diragukan lagi. Kepemimpinan Rasulullah tidak dapat ditiru seutuhnya, namun sebagai umat Islam hendaknya berusaha meneladani kepemimpinan Beliau.

Kepemimpinan pendidikan islam ini juga dappat di definisikan sebagai proses hubungan antar-individu yang di dalamnya seseorang mempengaruhi sikap, kepercayaan dan perilaku orang lain. Berdasarkan beberapa arti kepemimpinan di atas, Islam memandang kepemimpinan

113 Surat Al-Qalam (68:4) https://quran.kemenag.go.id/index.php/sura/68 diakses pada tanggal 11 September 2020 
sebagai suatu amanah yang berdasarkan padaa al-Quran dan as-Sunnah untuk mempengaruhi perilaku seseorang dalam mencapai tujuan.

\section{Fungsi dan Tugas Kepemimpinan Pendidikan Islam}

Stephen P.Robin mengungkapkan urgensi fungsi kepemimpinan bagi suatu organisasi itu terletak pada kebutuhan akan koordinasi dan kendali. Tujuan organisasi tidak bisa dicapai jika masing-masing individu yang terorganisasi didalamnya berjalan secara fragmentalis tanpa koordinasi dan terkendali. Aturan,uraian tugas,kebijakan dan hierarki otoritas merupakan gambaran dari syarat yang diciptakan untuk memudahkan koordinasi dan kendali. Selain itu, kepemimpinan menyumbang ke pemaduan berbagai aktifitas pekerjaan, koordinasi komunikasi antara subunit organisasi, pemantauan kegiatan, dan pengawasan penyimpangan dari standar. Tidak ada sejumlah aturan dan pengaturan dapat menggantikan pemimpin yang berpengalaman yang dapat membuat keputusan yang cepat dan menentukan. ${ }^{114}$

Sedangkan, Soekarto Indra fachrudi pada arah yang sama menyimpulkan bahwa fungsi kepemimpinan pada dasarnya dapat dibagi menjadi dua macam sebagai berikut: 115

1. Fungsi yang bertalian dengan tujuan yang hendak dicapai, diantaranya:

a) Memikirkna dan merumuskan dengan teliti, tujuan kelompok serta menjelaskan kepada angota-anggotanya supaya dapat bekerja sama mencapai tujuan tersebut; b) Memberi dorongan kepada anggoota kelompok untuk menganalisis situasi supaya dapat dirumuskan rencana kegiatan kepemimpinan yang dapat member harapan baik; c) Membantu anggota kelompok dalam mengumpulkan keterangan yang perlu supaya dapat mengadakan pertimbangan yang sehat; d) Menggunakan kesanggupan dan minat khusus anggota kelompok; e) Memberi dorongan kepada setiap anggota kelompok untuk melahirkan perasaan dan pikirannya dan memilih buah pikiran yang baik dan berguna dalam pemecahan masalah yang dihadapi oleh kelompok; f) Memberi kepercayaan dan tanggung jawab kepada anggota dalam melaksanakan tugas sesuai dengan kemampuan masing-masing demi kepentingan bersama.

2. Fungsi yang bertalian dengan penciptaan suasana pekerjaan yang sehat dan sambil memeliharanya diantaranya: a) Memupuk dan memelihara kebersamaan dalam kelompok; b) Mengusahakan suatu tempat bekerja yang menyenangkan sehingga dapat memupuk kegembiraan dan

114 Stephen P. Robbin, Perilaku Organisasi; Konsep, Kontroversi, Aplikasi, Jilid 2, Terj. Hadyana Pujaatmaka dan Benyamin Mohan (Jakarta : Prenhallindo, 2001), hal. 41.

115 Soekarto Indra Fachrudi. Bagaimana Memimpin Sekolah yangEfektif. (Bogor: Ghalia Indonesia, 2006), hal 3-4. 
semangat bekerja dalam pelaksanaan tugas; c) Dapat mendorong dan memupuk perasaan para anggota bahwa mereka termasuk dalam kelompok dan merupakan bagian dari kelompok. Semangat kelompok dapat dibentuk melalui penghargaan terhadap usaha setiap anggota atau kelompok demi kepentingan kelompok dan melalui social activities; d) Menggunakan kelebihan yan dimilikinya bukan untuk berkuasa atau mendominasi, melainkan sebagai sumbangan terhadap kelompok demi mencapai tujuan bersama.

Kenyataannya yang terjadi pada kepemimpinan pendidikan islam berbeda dengan sosok manajer, administrator maupun jabatan tertinggi dalam dunia pendidikan. Pimpinan dalampendidikan Islam adalah sosok yang memiliki konsep masyarakat komprehenshif yang luas serta berkaitan langsung dengan tujuan pendidikan Islam. tujuan tersebut sangan berpengaruh dengan semangat orientasi internasional yang masyur dalam hadis Nabi, yang memerintahkan umatnya untuk mencari ilmu sampai ke negeri Cina. Makna tersirat didalam hadist tersebut ialah, menganjurkan kepada umatnya untuk terus mengembara mencari ilmu. Sehingga ketika kembali nantinya akan memberikan pencerahan, pemberdayaan bagi yang lainnya. Hal ini menandakan peranan dari pemimpin dan pendidikan islam mempunyai tugas yang berkaitan dengan sosial kehidupan masyarakat.

Sumber lain menyebutkan secara operasional fungsi kepemimpinan dapat diklasfikasikan menjadi lima fungsi pokok, ${ }^{116}$ yaitu:

1. Fungsi Intruksi. Fungsi ini bersifat komunikasi satu arah. Pemimpin sebagai komunikator, pihak yang menentukan apa, bagaimana, bilamana dan dimana perintah tersebut dilaksanakan agar keputusan dapat dikerjakan secara efektif.

2. Fungsi Konsultasi. Fungsi ini bersifat komunikasi antar dua arah. Pada tahap pertama, usaha menetapkan keputusan, pemimpin kerap kali memerlukan bahan perimbangan dari orang-orang yang dipimpinnya yang memiliki berbagai informasi dalam menetapkan keputusan. Tahap berikutnya adalah konsultas dari pemimpin pada orang-orang yang dipimpin dapat dilakukan setelah keputusan ditetapkan dan sedang dalam pelaksanaan.

3. Fungsi Partisipasi. Pada fungsi ini pemimpi berusaha mengaktifkan orang-orang yang dipimpinnya, baik dalamkeikutsertaan pengambilan keputusan maupun dalam pelaksanaannya.

4. Fungsi Delegasi. Fungsi ini dilaksanakan dengan memberikan pelimpahan wewenang mmbuat keputusan,baik melalui persetujuan maupun tanpa melalui persetujuan dari pemimpin.

5. Fungsi Pengendalian. Fungsi ini bermaksud bahwa kepemimpinan yang efektif mampu mengatur aktivitas anggotanya secara terarah dan

116 Soekarto Indra Fachrudi. Bagaimana Memimpin Sekolah yangEfektif. (Bogor: Ghalia Indonesia, 2006), hal. 94-95 
dalamkoordinasi yang efektif, sehingga memungkinkan tercapainya tujuan bersama secara maksimal.

\section{Tugas Kepemimpinan Pendidikan Islam}

Seorang pemimpin memiliki tugas yaitu membawa organisasinya untuk bekerja bersama sesuai dengan tanggung jawab dan pembagian tugasnya masing-masing. Kemudian membawa organisasi ke arah pencapaian tujuan yang diharapkan. Selain itu pemimpin juga bertugas dalam mengawasi, meluruskan, memandu, membenarkan, menerjemahkan, mengorganisasi, dan mentransformasikan harapan dari anggota orgnisasi.

Berdasarkan konteks nilai dan norma sosial, tugas dari pemimpin adalah membuat organisasi sebagai suatu sistem sosial yang menyenangkan bagi anggota organisasinya, sehingga organisasi menjadi satu tempat berinteraksi dan aktualisasi diri bagi anggotanya.117 Suatu organisasi diumpamakan seperti tubuh, jika ada salah satu anggota tubuh yang merasa sakit maka anggota lainnya akan merasa tidak nyaman. Organisasi yang sehat akan membawa kesenangan dan ketenangan bagi anggotanya dalam melaksanakan kegiatan organisasi, sehingga tujuan dari organisasi yang telah direncanakan dapat tercapai sesuai target.

James A.F. Stoner memaparkan tugas utama dari pemimpin yaitu:

1. Pemimpin bekerja dengan orang lain

2. Pemimpin tanggung jawab dan mempertanggung jawabkan (akuntabilitas)

3. Pemimpin menyeimbangkan pencapaian tujuan dan prioritas

4. Pemimpin berfikir secara analitis dan konseptual

5. Pemimpin harus mampu menjadi seorang mediator (penengah)

6. Pemimpin adalah politis dan diplomatik. Seorang pemimpin harus mampu mengajak dan melakukan kompromi. Sebagai seorang diplomasi seorang pempimpin arus dapat mewakili organisasinya.

7. Pemimpin membuat keputusan yang sulit dan harus bisa memecahkan masalah

Berdasarkan pemaparan diatas pemimpin merupakan seorang yang paling menonjol dan memiliki tanggung jawab penuh terhadap organisasinya. Sosok pemimpin merupakan seorang yang memiliki anailisis tajam terhadap keadaan lembaga dan kondisi yang dihadapi. Keputusan yang diambil menjadi penentu bagi keberhasilan organisasinya. Pemimpin tidak dapat bekerja sendiri, melainkan membutuhkan dan menggerakkan orang lain secara sukarela tanpa tekanan mau bekerja sama guna mencapai cita-cita oeganisasinya.

117 Imam Machali dan Ara Hidayat, The Handbook Of Education.... hal. 93. 


\section{Syarat dan Ciri-ciri Kepemimpinan Pendidikan Islam}

Seorang pemimpin hendaknya tidak berlaku sewenang-wenang dalam memimpin. Layaknya sebuah cermin, ia selalu menjadi teladan dan contoh bagi orang-orang yang dipimpinnya. ${ }^{118}$ Dalam lembaga pendidikan Islam, madrasah misalnya. Kepala madrasah-lah yang menjadi teladan, dalam pondok pesantren Kiyai adalah cerminan utama. Seorang pemimpin bukan hanya menunjukkan sifat yang sempurna melainkan juga sikap sempurna (perfect attitude).

Pola kepemimpinan di lembaga pendidikan tidak sekedar melaksanakan tugas rutin yang sama setiap harinya. Warga sekolah/madrasah memiliki tugas pokok dan fungsi yang dilakukan. Begitupun kompetensi yang dimiliki oleh pemimpin di lembaga pendidikan yang diatur dalam Peraturan Mentri Agama No 29 Tahun 2014, dimana kepala sekolah wajib memiliki kompetensi: kepribadian, manajerial, kewirausahaan, supervisi dan sosial.

Agar suatu lembaga pendidikan mempunyai daya dukung dalam era desentralisasi pendidikan, Mulyasa mengungkapkan dalam bukunya tentang Manajemen dan Kepemimpinan Kepala Sekolah diperlukan kepala sekolah ideal yang mempunyai ciri-ciri khusus diantaranya sebagai berikut: 119

1. Melimpahkan wewenang. Seorang kepala sekolah tidak harus membuat keputusan sendiri dalam segala hal, namun ada beberapa yang lebih baik diputuskan sendiri. kemudian sisanya diserahkan wewenangnya kepada kelompok-kelompok yang ada dibawah pengawasannya.

2. Merangsang kreativitas. Perubahan dalam lembaga pendidikan tidak harus berasal dari pemimpin, sebab kemampuan pemimpin terbatas. Oleh karena itu pemimpin justru perlu merangsang kreativitas di kalangan orang-orang yang di pimpinnya guna menciptakan hal baru yang menghasilkan kinerja bermutu.

3. Memberi semangat dan motivasi. Melakukan pembaharuan dan inovasi merupakan cara akurat meningkatkan mutu lembaga pendidikan. Jika ada beberapa anggota yang mulai kendor bekerja, bahkan terkadang melalaikan tugasnya, maka pemmpin berkewajiban memberikan semangat dan memotivasi bawahannya.

4. Membicarakan persaingan. Jika membahas tentang mutu, maka akan terlintas adanya mutu tinggi dan mutu rendah. Kemudian melakukan perbandingan dengan lembaga pendidikan lain. Nampaknya ketika melalukan analisis persaingan membutuhkan perencanaan yang matang

118 DPPAI UII, Menjadi Pemimpin Muslim Sejati. (Yogyakarta: DPPAI UII, 2013), hal. 28-29.

119 Mulyasa, Manajemen dan Kepemimpinan Kepala Sekolahal. (Jakarta: Bumi Aksara, 2013), hal. 59-54. 
di awal, dengan memanfaatka kekuatan, kelemahan, peluang dan ancaman. Atau lebih dikenal dengan analisis SWOT.

5. Bekerja sama dengan masyarakat. Dalam era desentralisasi pendidikan saat ini, bekerja sama sengan masyarakat amatlah urgen. Pasalnya kebutuhan pendidikan di masing-masing daerah berbeda antar satu dengan yang lainnya. Salah satu dari ciri-ciri kepemimpinan ini harus dimiliki oleh Pemimpin di lembaga pendidikan, guna memecahkan masalah-masalah yang muncul supaya dapat diselesaikan dengan tuntas.

Mulyasa menjelaskan dalam jurnal Ardhana Januar Mahardhani tentang strategi kepala sekolah sebagai sentral figur lembaga pendidikan yang dipimpinnya. Berikut ini penjelasannya:

1. Sebagai evaluator maka kepala sekolah harus melakukan langkah awal yaitu, melakukan pengukuran seperti kehadiran, kerajinan dan pribadi para guru, tenaga kependidikan, administrator sekolah dan siswa. Data hasil pengukuran tersebut kemudian ditimbang - timbang dilakukan evaluasi. Evaluasi yang bisa dilakukan, antara lain terhadap program, perlakuan guru terhadap siswa, hasil belajar, perlakuan belajar, perlengkapan belajar, dan latar belakang guru.

2. Sebagian manajer maka kepala sekolah harus memerankan fungsi manajerial dengan melakukan proses perencanaan, pengorganisasian, menggerakkan dan mengoordinasikan (planning, organizing, actuating, dan controling). Merencanakan berkaitan dengan menetapkan tujuan dan strategi untuk mencapai tujuan tersebut. Mengorganisasikan berkaitan dengan mendesain dan membuat struktur organisasi. Termasuk dalam hal ini adalah memilih orang-orang yang kompeten dalam menjalankan pekerjaan dan mencari sumber daya pendukung yang paling sesuai. Menggerakkan adalah mempengaruhi orang lain agar bersedia menjalankan tugasnya secara sukarela dalam rangka mencapai tujuan yang diinginkan. Mengontrol adalah membandingkan apakah yang dilaksanakan telah sesuai dengan yang direncanakan.

3. Sebagai administator maka kepala sekolah memiliki dua tugas utama. Pertama, sebagai pengendalian struktur organisasi, yaitu mengendalikan bagaimana cara pelaporan, dengan siapa tugas tersebut harus dikerjakan dan dengan siapa berinteraksi dalam mengerjakan tugas tersebut. Kedua, melaksanakan administrasi substantive yang mencakup administrasi kurikulum, kesiswaan, personalia, dan administrasi umum.

4. Sebagai supervisor maka kepala sekolah berkewajiban untuk memberikan pembinaan atau bimbingan kepada para guru dan tenaga kependidikan serta administrator lainnya. Namun, sebelum memberikan pembinaan dan bimbingan kepada orang lain maka kepala sekolah harus membina dirinya sendiri. Supervisi bias dilakukan ke dalam kelas atau dalam kantor tempat orang-orang bekerja. 
5. Sebagai leader maka kepala sekolah harus mampu menggerakkan orang lain agar secara sadar dan sukarela melaksanakan kewajibannya secara baik sesuai dengan yang diharapkan pimpinan dalam rangka mencapai tujuan. Kepemimpinan kepala sekolah terutama ditujukan kepada para guru karena merekalah yang terlibat secara langsung dalam proses pendidikan. Namun demikian, kepemimpinan kepala sekolah juga ditujukan kepada para tenaga kependidikan dan administrator lainnya.

6. Sebagai inovator maka kepala sekolah melaksanakan pembaruan terhadap pelaksanaan pendidikan di sekolah yang dipimpin berdasarkan prediksi yang telah dilakukan sebelumnya. Misalnya saja inovasi berupa pembaruan kurikulum dengan memperhatikan potensi dan kebutuhan daerah tempat sekolah tersebut berada. Inovasi itu bisa dilakukan terhadap materi kurikulum (isi kurikulum) ataupun strategi proses belajar mengajar.

7. Sebagai motivator maka kepala sekolah harus memberikan motivasi kepada guru dan tenaga kependidikan dan administratir sehingga mereka bersemangat dan bergairah dalam menjalankan tugasnya dalam rangka meningkatkan mutu pendidikan. Motivasi bisa diberikan dalam bentuk hadiah atau hukuman baik fisik mampu nonfisik. Namun, dalam memberikan motivasi ini harus dipertimbangkan rasa keadilan dan kelayakannya. Dalam hal ini penting bagi kepala sekolah untuk menciptakan iklim yang kondusif.

\section{Analisis Syarat dan Ciri-ciri Kepemimpinan Pendidikan Islam}

Riset mengenai kepemimpinan menurut Collons tidak mengungkapkan satu sifat tunggal yanag dimiliki semua pemimpin yang berhasil, tetapi sejumlah ciri umum yang dimiliki banyak diantara mereka. Diantaranya memiliki sifat: (1) manusiawi; (2) memandang jauh ke depan; (3) inspiratif (kaya akan gagasan); (4) percaya diri. Pemimpin yang manusiawi adalah penting, karena dalam lembaga pendidikan kita bersinggungan dengan manusia. Jika tidak memperlakukan dengan manusiawi maka akan timbul perawanan. Pemimpin yang tidak punya visi sekaligus tidak percaya diri dipastikan lembaga yang dipimpinnya tidak akan kompetitif dengan sekolah lainnya, karena bergerak dalam ranah rutinan saja. ${ }^{120}$

Fenomena kedua yang ditemukan dalam Jurnal Agama dan Hak Azazi Manusia karya Ainun Najib dengan judul Konstruksi Pemimpin Ideal untuk Indonesia menyebutkan berberapa kriteria pokok atau patokan utama untuk menjadi pemimpin yang ideal yang ditawarkan oleh Islam untuk negara Indonesia yang plural antara lain sebagaimana penjelasan di bawah:

1. Pemimpin yang Memiliki Talenta Kepemimpinan

120 Syaiful Sagala, Administrasi Pendidikan Kontemporer, (Bandung: Alfabeta, 2013), hal. 148-149. 
Pada dasarnya mengetahui secara pasti atau memberikan penilaian pada calon pemimpin yang memiliki talenta kepemimpinan adalah hal yang sangat subjektif dan relatif. Nemun demikian, dalam masalah memilih pemimpin, Islam memberikan perhatian intens dalam memberikan solusinya.

2. Pemimpin yang Bertanggung Jawab

Pemimpin yang ada di Indonesia pada saat ini, meskipun tidak merata pada jumlah keseluruhannya namun masih banyak yang mengambil kesempatan dari amanah jabatan untuk meraup keuntungan. Sehingga kesan nyata adalah pemimpin yang mengumpulkan harta kekayaan bukan untuk mengayomi dan mengurus rakyat dan tatanan kenegaraan. Akibatnya masyarakat yang sengsara dan negara pun tidak berkembang karena dirugikan oleh pemimpin yang memperkaya diri ini padahal ia diangkat menjadi pemimpin oleh rakyat yang seperti ini lah salah satu contoh dari pemimpin yang tidak bertanggung jawab hanya memikirkan kepentingan pribadi.

3. Pemimpin yang Berakhlak Mulia dan Penyayang

Seorang pemimpin selain harus memiliki sifat tegas, talenta dalam kepemimpanan, dan kreatif, ia juga harus memiliki prinsip moral dan etika bangsa dalam kehidupan bernegara. Karena pemimpin adalah panutan atau teladan bagi yang dipimpin, maka bagaiamana nasib suatu bangsa jika pemimpinnya tidak bermoral, tentu akan berdampak negatif pada kehidupan rakyatnya. Dalam arti, dampak dari peran seorang pemimpin baik dari aspek baik dan buruknya dapat berpengaruh kepada orang-orang yang dipimpin atau rakyat. ${ }^{121}$

Berpindah dari yang bersifat umum, ke fenomena yang terjadi di lembaga bendidikan khususnya sekolah. Pada tingkat sekolah, kepala sekolah sebagai figur kunci dalam mendorong perkembangan dan kemajuan sekolah. Kepala sekolah tidak hanya meningkatkan tanggung jawab dan otoritasnya dalam program-program sekolah, kurikulum dan keputusan personel, tetapi juga memiliki tanggung jawab untuk meningkatkan akuntabilitas keberhasilan siswa dan programnya. Kepala sekolah harus pandai dalam memimpin kelompok dan pendelegasian tugas dan wewenang.

Pada jurnal Dimensi Pendidikan dan Pembelajaran yang terbit tahun 2015 lalu dibahas mengenai sosok kepala sekolah yang ideal dengan upaya profesionalisme yang dilakukannya. Kepala sekolah dianggap sebagai salah satu unsur yang strategis dalam meningkatkan mutu pendidikan. Upaya peningkatan profesionalisme kepala sekolah merupakan proses yang berkaitan dengan keseluruhan organisasi

121 Akbar Tanjung, Islam, "Demokrasi dan Tantangan Global Akademik", dalam Jurnal Kebudayaan, vol, 4, No. I, (November, 2009), hal. 102. 
sekolah, serta harus dilakukan secara berkesinambungan. Profesionalisme kepala sekolah harus secara sinergis dilaksanakan dengan melibatkan pengawas sekolah.

Upaya peningkatan profesionalisme kepala sekolah tidak akan terwujud, tanpa adanya motivasi dan kesadaran internal dari kepala sekolah, serta semangat untuk mengabdi, yang akan melahirkan visi sekolah maupun kemampuan konsepsional yang jelas dari kepala sekolah. Ini merukan faktor yang penting, tanpa adanya kesadaran dan motivasi semangat untuk mengabdi, maka semua usaha yang dilakukan tidak akan memberikan hasil yang optimal, yang akan menyebabkan realisasinya juga tidak optimal.

Secara profesional, menurut Wahjosumidjo, kepala sekolah memiliki tugas-tugas sebagai berikut: ${ }^{122}$

a. Kepala sekolah berperilaku sebagai saluran komunikasi di lingkungan sekolah yang dipimpinnya.

b. Kepala sekolah bertindak dan bertanggung jawab atas segala tindakan yang dilakukan oleh guru, staf, dan pegawai lainnya yang ada disekolah.

c. Dengan waktu dan sumber yang terbatas, kepala sekolah harus mampu menghadapi berbagai persoalan.

d. Kepala sekolah harus berfikir secara analitik dan konsepsional.

e. Kepala sekolah adalah seorang mediator atau juru penengah.

f. Kepala sekolah adalah seorang politisi.

g. Kepala sekolah adalah seorang diplomat.

h. Kepala sekolah harus mampu mengambil keputusan - keputusan sulit.

Beberapa penelitian dan hasil karya ilmiyah yang berupa buku, juga belum penulis temukan yang lebih spesifik membahas syarat dan ciri-ciri kepemimpinan yang ideal dan bisa diterapkan disegala situasi dan kondisi yang ada, hal tersebut sangat mustahil karena tidak ada satupun manusia yang sempurna. Namun terkait hal ini terdapat beberapa indikator yang penulis peroleh dari beberapa reverensi untuk syarat dan ciri-ciri kepemimpinan ideal:

1. Memiliki pengetahuan yang luas dan kemampuan analitik yang kuat.

Pengetahuan seseorang ini, diperoleh berdasarkan informasi yang didapatkan, semakin banyak pemimpin mencari informasi, semakin banyak pula yang ia ketahui. Hal ini ke depannya akan menambah rasa hormat tenaga pendidik yang lainnya, karena pemimpin berpengetahuan luas, dan juga mampu menganalisis informasi tersebut dengan akurat. ${ }^{123}$

122 Wahjosumidjo.. Kepemimpinan Kepala Sekolahal. (Jakarta: PT Raja Grafindo Persada, 2002), hal. 97.

123 Mar'at, Pemimpin dan Kepemimpinan, (Jakarta: Ghalia Indonesia, tt), hal. 72. 
Mengumpulkan informasi, menganalisis pembentukan konsep. Mengumpulkan latar belakang informasi dari berbagai sumber sebelum berpendapat tentang suatu peristiwa atau masalah. Hal itu dilakukan secara terus menerus untuk selalu memperoleh informasi yang baru. ${ }^{124}$

2. Kapasitas integratif, keterampilan komunikatif dan keterampilan mendidik. Membuat pembaharuan dengan menggabungkan beberapa aspek yang sesuai, mampu berkomunkasi dan mengajarkan bawahan yang belum mengetahui dengan benar.

3. Rasionalitas, obyektivitas dan pragmatis Berpikir rasional dan melakukan penilaian secara objektif, tidak berat sebelah dan membuat semuanya lebih praktis tanpa berbelit-belit.

4. Keteladanan, adaptabilitas dan fleksibilitas.

Pemimpin menjadi teladan dalam lembaga yang dipimpin. Ibarat kaca pemimpinlah yang menjadi panutan atau kiblat bagi bawahannya. Lalu harus memiliki sikap adaptabilitas dan fleksibilitas kemampuan beradaptasi dan menyesuaikan diri dengan lingkungannya. Kemampuan beradaptasi dan tahu sebanyak mungkin situasi yang dapat dimasuki. ${ }^{125}$ Mampu mempergunakan berbagai konsep, dan pandangan-pandangan jika memecahkan masalah atau sedang mengambil suatu keputusan ${ }^{126}$

5. Ketegasan, keberanian dan orientasi masa depan.

Ketegasan adalah kemampuan untuk dapat menhadapi orang lain tanpa menimbulkan penghinaan. Ketegasan juga diartikan sebagai kemampuan untuk melaksanakan hal yang tepat pada watunya. ${ }^{127}$ Menunjukkan dirinya selalu siap untuk mengambil suatu keputusan. dan memiliki kemampuan untuk mengetahui bahwa suatu keputusan diperlukan.

124 Abdul Ghofar " Fleksibilitas Kepemimpinan Pendidikan: Upaya Menciptakan Budaya Sekolah yang Berkarakter" Jurnal Al Tarbawi Al Haditsah Vol 1 No 1.

125 Erman Anom, “Kepemimpinan Visioner dalam Mewujudkan Keutuhan NKRI" Lex Jurnalica Vol.5 No. 3, Agustus 2008, hal. 157.

${ }^{126}$ Abdul Ghofar " Fleksibilitas Kepemimpinan Pendidikan: Upaya Menciptakan Budaya Sekolah yang Berkarakter" Jurnal Al Tarbawi Al Haditsah Vol 1 No 1

127 Mar'at, Pemimpin dan Kepemimpinan... hal. 73. 


\section{Kesimpulan}

Arti pemimpin dan kepemimpinan, merupakan dua hal yang saling berkaitan. Pemimpin merupakan subjek dari yang dipimpin. Kepemimpinan (leadership) merupakan proses atau hubungan yang terjalin antara pemimpin dan anggotanya, sehingga dapat tergerak untuk melakukan atau tidak melakukan pekerjaan sesuai dengan tujuan yang direncanakan.

Adapun indikator dari ciri-ciri kepemimpinan pendidikan Islam berbeda antara satu dengan lainnya. Namun dari beberapa referensi yang diperoleh pemimpin yang ideal menunjukkan sikap positif sifat yang baik kepada anggotanya. Jika dikembalikan kepada hakikat manusia bahwa mereka tidak ada yang sempurna, maka konsep kepemimpinan yang ideal dapat terjadi jika pemimpin tersebut berhasil mengharumkan lembaga atau organisasinya sesuai dengan tujuan yang dicita-citakan bersama.

\section{Daftar Pustaka}

Abdul Ghofar "Fleksibilitas Kepemimpinan Pendidikan: Upaya Menciptakan Budaya Sekolah yang Berkarakter" Jurnal Al Tarbawi Al Haditsah. Vol 1. No 1.

Akbar Tanjung. Islam "Demokrasi dan Tantangan Global Akademik", dalam Jurnal Kebudayaan. Vol. 4. No. I. November. 2009.

Anom, Erman. "Kepemimpinan Visioner dalam Mewujudkan Keutuhan NKRI" Lex Jurnalica. Vol. 5 No. 3, Agustus 2008.

Asf, Jasmani dan Syaiful Mustofa. Supervisi Pendidikan: Terobosan Baru dalam Peningkatan Kinerja Pengawas Sekolah dan Guru. Jogjakarta: AR-RUZZ MEDIA. 2013.

DPPAI UII, Menjadi Pemimpin Muslim Sejati. Yogyakarta: DPPAI UII. 2013.

Fachrudi, Soekarto Indra. Bagaimana Memimpin Sekolah yangEfektif. Bogor: Ghalia Indonesia. 2006.

Ghofar, Abdul "Fleksibilitas Kepemimpinan Pendidikan: Upaya Menciptakan Budaya Sekolah yang Berkarakter" Jurnal Al Tarbawi Al Haditsah. Vol 1 No 1.

Hadi, Sutrisno. Metodologi Riset. Yogyakarta: Pustaka Pelajar. 2015.

Harahap, Nursapia. Penelitian Kepustakaan, Jurnal Iqra' Volume 08 No.01 Mei. 2014.

Machali, Imam dan Ara Hidayat. The Handbook Of Education Management. Jakarta: Kencana. 2018.

Makawimbang, Jerry H., Kepemimpinan Pendidikan yang Bermutu. Bandung: Alfabeta. 2012.

Mar'at. Tt. Pemimpin dan Kepemimpinan. Jakarta:Ghalia Indonesia.

Matondang. Kepemimpinan: Budaya Organisasi dan Manajemen Strategik. Yogyakarta: Graha Ilmu. 2008.

Muhammad 'Abduh dan Muhammad Rasyid Ridha. Tafsir al-Mannar (alQahirah: Dar al-Mannar). 1947. 
Mulyasa. 2013. Manajemen dan Kepemimpinan Kepala Sekolah. Jakarta: Bumi Aksara.

Nawas Syarif, "Menyambut Kepemimpinan Ideal di tengah Maraknya Kepemimpinan Transaksional" http://pemberiilmu.blogspot.com/2013/02/menyambutkepemimpinan-ideal-di-tengah.html (diakses pada tanggal 5 Oktober 2018).

Robbin, Stephen P. 2001. Perilaku Organisasi; Konsep, Kontroversi, Aplikasi, Jilid 2, Terj.: Hadyana Pujaatmaka dan Benyamin Mohan. Jakarta : Prenhallindo.

Sagala, Syaiful. Administrasi Pendidikan Kontemporer. Bandung: Alfabeta. 2013.

Surat Al-Qalam (68:4) https://quran.kemenag.go.id/index.php/sura/68 diakses pada tanggal 11 September 2020

Wahjosumidjo. Kepemimpinan Kepala Sekolah. Jakarta: PT Raja Grafindo Persada. 2002.

Zainuddin. Muhadi dan Abd. Mutaqim, Studi Kepemimpinan Islam: Konsep, Teori, dan Praktiknya dalam Sejarah. Yogyakarta: SUKA Press. 2012. 